Abstracta Iranica Abstracta Iranica

Revue bibliographique pour le domaine irano-aryen

Volume 26 | 2005

Comptes rendus des publications de 2003

\title{
"Le mètre du Draxt asûrîg ». Orientalia Suecana, vol. LI-LII (2002-2003), pp. 327-336.
}

\section{Charles-Henri de Fouchécour}

\section{Q OpenEdition \\ 12 Journals}

Édition électronique

URL : http://journals.openedition.org/abstractairanica/1933

ISSN : 1961-960X

Éditeur :

CNRS (UMR 7528 Mondes iraniens et indiens), Éditions de l'IFRI

Édition imprimée

Date de publication : 15 mai 2005

ISSN : 0240-8910

\section{Référence électronique}

Charles-Henri de Fouchécour, « « Le mètre du Draxt asûrîg ». Orientalia Suecana, vol. LI-LII (2002-2003),

pp. 327-336. », Abstracta Iranica [En ligne], Volume 26 | 2005, document 362, mis en ligne le 07

décembre 2005, consulté le 25 septembre 2020. URL : http://journals.openedition.org/

abstractairanica/1933

Ce document a été généré automatiquement le 25 septembre 2020.

Tous droits réservés 


\title{
« Le mètre du Draxt asûrîg ». Orientalia Suecana, vol. LI-LII (2002-2003), pp. 327-336.
}

\author{
Charles-Henri de Fouchécour
}

1 L'article prend le numéro 12 dans la série de l'A. EVLIA. Il débute par un rappel des principes auxquels est parvenue la recherche de G. Lazard. A) Les principes de la versification en parthe et en moyen-perse sont: le rythme est accentuel, les ictus (temps forts revenant à intervalles réguliers) tendent à coïncider avec les accents des mots, les syllabes sont, soit légères (brèves, ou longues des mots accessoires ou en position faible), soit lourdes (autres longues), enfin l'ictus n'affecte qu'une syllabe lourde. Le pied, unité rythmique de base, est une syllabe lourde portant l'ictus, précédée de syllabes indifférentes, en nombre variable. Dans un mètre, le nombre de syllabes lourdes par pied est limité. B) Ayant identifié plusieurs types de mètres parthes et moyen-perses, l'A. a pu les mettre en rapport avec des mètres usuels de la poésie persane, « selon certaines règles ", rappelle-t-il. Il s'agit du célèbre motaqāreb (narratif et non narratif), une variété du hazaj et le robāi . Les travaux de Benveniste et de Henning sur le poème parthe du Draxt asûrîg vont se trouver ici considérablement élargis. L'A. montre que chaque hémistiche du poème comporte deux ictus. Les hémistiches du poème les plus nombreux comportent deux mots principaux. Il répond alors à la question: qu'en est-il des hémistiches comportant plus de deux mots accentuables? Un examen minutieux lui permet d'affirmer que, sur un total de 82 hémistiches, cinq seulement restent problématiques. Un tableau faisant apparaître la place des ictus dans l'ensemble du poème lui permet de dégager la structure du mètre du poème : chaque vers a deux hémistiches, chacun comprend deux pieds, chaque pied est fait d'une syllabe lourde portant l'ictus et précédée d'une à trois syllabes, dont deux seulement peuvent être lourdes. Or les rythmes naturels du persan sont à peu près les mêmes que ceux du moyen-perse. De sorte que « la versification persane classique reste d'une manière ou d'une autre en rapport avec celle du moyen-iranien occidental» (p. 334). En conclusion, on trouvera un rapprochement nouveau fait entre le mètre du Draxt asûrîg et les mètres persans parmi les plus fréquents, eux aussi à base 
quadrisyllabique, ramal et hazaj. Et une différence : les vers préislamiques (sauf deux exceptions) ont une césure médiane leur donnant une structure symétrique, tandis que la poésie persane "préfère les mètres catalectiques ", où manque une syllabe au pied final (maqșūr ou maḥ̂ūuf), où manque aussi la césure médiane.

INDEX

Thèmes: 11.1.1. Littérature persane classique

Mots-clés : Poésie

Keywords : poésie persane, Poetry, Persian poetry

\section{AUTEURS}

\section{CHARLES-HENRI DE FOUCHÉCOUR}

Fondateur de la revue Abstracta Iranica - Paris 